\title{
Redefining Nationhood and Nationality through Historiographic Metafiction in the Shadow Lines
}

\author{
Nayana K. ${ }^{1}$ \& Manjula K. T. ${ }^{2}$ \\ ${ }^{1}$ Research Scholar, College of Humanities and Social Science, Srinivas University, \\ Mangalore, India. \\ Orcid ID: 0000-0002-3064-1197, E-mail: nirupin22@gmail.com \\ ${ }^{2}$ Research Professor, College of Humanities and Social Science, Srinivas University, \\ Mangalore, India. \\ Orcid ID: 0000-0002-2459-1103, E-mail: manjula.kalyat@gmail.com
}

Area/Section: English Literature.

Type of the Paper: Analytical Paper.

Type of Review: Peer Reviewed as per $|\mathrm{C}| \mathrm{O}|\mathrm{P}| \mathrm{E} \mid$ guidance.

Indexed in: OpenAIRE.

DOI: https://doi.org/10.5281/zenodo.5855127

Google Scholar Citation: IJMTS

\section{How to Cite this Paper:}

Nayana, K., \& Manjula, K. T., (2022). Redefining Nationhood and Nationality through Historiographic Metafiction in the Shadow Lines. International Journal of Management, Technology, and Social Sciences (IJMTS), 7(1), 11-20.

DOI: https://doi.org/10.5281/zenodo.5855127

International Journal of Management, Technology, and Social Sciences (IJMTS)

A Refereed International Journal of Srinivas University, India.

CrossRef DOI: https://doi.org/10.47992/IJMTS.2581.6012.0174

(C) With Author.

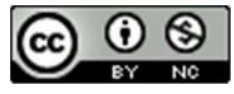

This work is licensed under a Creative Commons Attribution-Non-Commercial 4.0 International License subject to proper citation to the publication source of the work.

Disclaimer: The scholarly papers as reviewed and published by the Srinivas Publications (S.P.), India are the views and opinions of their respective authors and are not the views or opinions of the SP. The SP disclaims of any harm or loss caused due to the published content to any party. 


\title{
Redefining Nationhood and Nationality through Historiographic Metafiction in the Shadow Lines
}

\author{
Nayana K. ${ }^{1}$ \& Manjula K. T. ${ }^{2}$ \\ ${ }^{1}$ Research Scholar, College of Humanities and Social Science, Srinivas University, \\ Mangalore, India. \\ Orcid ID: 0000-0002-3064-1197, E-mail: nirupin22@gmail.com \\ ${ }^{2}$ Research Professor, College of Humanities and Social Science, Srinivas University, \\ Mangalore, India.
}

Orcid ID: 0000-0002-2459-1103, E-mail: manjula.kalyat@gmail.com

\begin{abstract}
Purpose: Postmodernism is a general movement that developed in the late 20th century across the arts, philosophy, art, architecture, and criticism, marking a disappearance from modernism. The term has been more often used to describe a historical age which followed after modernity. Postmodernism is a period of uprising which refers to ups and downs in each walk of life and the different disciplines of knowledge be it literary work, philosophy, or science. Postmodern literature revokes some modern literary methods by transforming them. Historiographic Metafiction is a contradictory term that consists of two opposite categories such as history and metafiction. It is having dual representations because such writings reflect the reality as well as fictional position. An attempt is made by the Post-colonial Indian English writers to liberate Indian English literature from the foreign bondage. Historical events such as agitations, migration, movements, refugees, colonial hegemony; social-economic and cultural problems like encounter of the east-west, caste, and class became the concerns of the writers.
\end{abstract}

Design/Methodology/Approach: This paper is prepared by making a study of Primary source and accumulating secondary data from educational websites and written publications. This qualitative research is carried out by studying and interpreting the existing knowledge on the subject. The paper tries to analyze the historiographic metafictional features as depicted in The Shadow Lines by Amitav Ghosh.

Findings/Result: After reviewing many articles, books and thesis it has been found that the paper aims to study Amitav Ghosh's notions like "Nationhood and National distinctiveness in "The Shadow Lines" as a reminiscence novel, highlights a few historical happenings like the Second World War, the Swadeshi movement, and the Partition of India in 1947 and communal uprisings in Bangladesh and India. The ardent nationalism upheld by the protagonist that is the narrator's grandmother is questioned and re-analysed. Ghosh searches for appropriateness of traditional identity such as nation and nationalism.

Originality/Value: This paper makes a study of the major character Thamma with special reference to her concerns of Nationhood and Nationality. The identity of Thamma in the novel is given prominence being a woman she stands for her thoughts and identifies her as an individual who faced tragedy but still who had the courage to raise her voice till the end.

Paper Type: Analytical Research paper.

Keywords: Postmodernism, Historiographic Metafiction, Redefining nationhood, Nationality.

\section{INTRODUCTION :}

The expression "Metafiction" was designed by William H. Gass in his book Fiction and the Figures of Life [1]. Writing style devised in the fictional writings makes the readers realize the fictional position of a text. Metafiction not only includes modernism but also overlays postmodernism. Metafictional writings are the collection of fictional events and features. The postmodern writers implement it to bring together their writings differently. Through metafictional writings, the writers form a fictional by the use artificial language and strange elements. Metafiction is applied as a narrative technique that 
knowingly takes the person who reads into an imaginary world. Metafiction was a term given to fictional writings which self-consciously and systematically draws attention to its status as an object to ask questions on the connection between fiction and reality. In providing a critique of their methods of construction, such writings not only examine the essential structures of narrative fiction, but they also explore the possible fictionality of the domain outside the fictional text.

\section{OBJECTIVE OF THE STUDY :}

The papers is analytical in nature and the objective of the study pertaining to The Shadow Lines: A Critique of Boundaries, attempts to problematize and understand the concept of boundaries, nationalism, patriotism, history and freedom. Further, efforts have been made to collect data and understand the manner in which studies have explored certain ethical standards which need to be followed for safeguarding social relationship, determine the research implications on which the present study is made.

\section{METHODOLOGY :}

The researcher has reviewed almost fifty research articles, Amitav Ghosh's "The Shadow Lines" as primary text, an attempt is made to review the secondary sources like the articles both national and international, interviews, reviews published by scholars and the author himself pertaining to the text. The online search was made to collect the database through Google scholar. The studies reviewed are peer reviewed journals, original research papers, National and International Publications. An attempt is made to apply Postmodern, Post-colonial and Pre-colonial theories in order to understand the topic as well as the text selected. A gist of concerned articles is given. In the references the works citied of the articles is mentioned. The researcher has referred and followed APA Manuel for the citation of the research papers.

\section{HISTORIOGRAPHIC METAFICTION :}

The believed postmodern literary technique, "Historiographic Metafiction" was termed by Linda Hutcheon in her book entitled A Poetics of Postmodernism, made its presence during the postmodern era. Postmodern writers have disseminated this literary technique by applying it in their writings. The term historiographic metafiction was coined by reconstructing fiction and history. It indicates the close association and effect between two diverse literary genres such as history and metafiction. It is a coming together of historical and fictional elements. It is mentioned to be self-reflexive ass it unexpectedly introduces the readers to historical facts, personalities along with fiction. Historiographic metafiction is ideally referred to as the self-consciousness of history as well as fiction since the writers rebuild and rethink as these writings show both fictitious and accurate occurrences [31].

Historiographic Metafiction is considered to be a postmodern literary method that portrays the conflicting thoughts and views of the writers in their work. Historiographic metafictional writings are areas of confrontation between fictional/historical and present and past. The clash of two contradictory viewpoints tries to create two worlds namely: the imaginative and the real world that takes the person who reads outside a literary text. The conflict of history with fiction fades away because the genuine elements begin from the literary texts.

One of the features of historiographic metafiction is rewriting history and rethinking the past. Fiction and history are two narrative genres that depict two distinct structures of two worlds: the fictional and the real. Characters and circumstances are transformed into an appropriate story shape in these writings. According to Linda Hutcheon, these two genres can be textual creations that are unoriginal in the sense that they rely on early inter-texts and inherently burden a historical metafix, at least not in history. There are, however, historical and fictional synthesises that can be used to achieve this equivalence. Amitav Ghosh has attempted to reconnect his readers to the external world of the texts by employing the technique of Historiographic Metafiction. Amitav Ghosh's writings are self-consciously metafictional and related, presenting historical references and personages. It's a narrative in which the narrator shows himself as a character as well as a narrator who symbolises Historiographic Metafiction [2]. 


\section{POSTCOLONIALISM :}

Postcolonialism is a state of mind, an essential step in the development of cultural processes and selfawareness. Ghosh's writing attempts to include his feeling of belonging, national identity, geography, rituals, national culture, and tradition, all of which are fundamental to postcolonial fiction.

Ghosh's post-colonial perspective allows him to show the melancholy of passivity, the failure of consumerism, disillusionment, the continual quest of truth and identity, unrequited love, and so on in The Shadow Lines. The issue of borders and maps is crucial in Ghosh's post-colonial context because he feels his people have suffered as a result of the divides generated by geographical limits. His works span the two literary genres of history and fiction. The confluence of these two genres is known as "historiographic metafiction" [3] [4].

\section{NARRATOR'S APPROACH :}

The Shadow Lines, written by Amitav Ghosh and published in 1988, was the author's response to another extraordinary event in the Post-Colonial Indian scene: the 1984 Anti-Sikh riots that erupted across the country in the aftermath of the assassination of then-Prime Minister Mrs. Indira Gandhi by her Sikh bodyguards. To begin with, the magnitude of these riots, which appeared to be State-sponsored, was comparable to the earlier sectarian agitation of the 1947 partition. The novel is centred on the narrator's experience as a young schoolboy during the communal riots in Calcutta in 1964, as well as his investigation of the gap in perception that pervades the recording of such occurrences. By adopting excessive and banal journalese that drowns the powerful, the author creates a great work that deals exclusively with the implications of the Partition and is particularly concerned with the Partition on the Bengal border. It is important to remember that Ghosh is the most well-known Indian-English novelist who is concerned with the partition of Bengal [5].

Amitav Ghosh employed the first-person narrative approach to explain historical events, political concerns, and his personal experiences in his novel The Shadow Lines. Historical events, situations, and characters are reconstructed and restructured in narrative fiction. Writers make use of narrative style, vocabulary, and ideology to teach readers how and what happened in history. In the opening lines of the novel the narrator makes a mention that Mayadebi, his father's aunt, visited England in 1939, thirteen years before he was born, with her husband and her son, Tridib [6].

The novel uses a complex and fragmented narrative technique to capture the perception of time and events. The novel is divided into two parts: 'Leaving' and 'Coming Home.' Both titles are ironic because Ghosh's handling of distances creates the impression that a person cannot 'go away' or 'come home.' The narrative shifts back and forth between the past and the present. Ghosh, expertly manipulating time, attempts to merge memories and present realities together. In the first half of the novel, Ghosh addressed the process of 'moving away,' or the dispersal of his characters across continents, as well as how interpersonal relationships across cultural barriers can/cannot be destroyed.

He explored the backdrop of political events bridging nearly two decades, post-colonial culture displacement, and the loss of the subcontinent's cultural unity in the part 'coming home.' Fixity points that were originally set by one's birth, home, or even nation are now shadow lines. As a result, there is a strong sensation that the protagonists are on their way to Calcutta, returning from Calcutta, headed to London, or returning to Calcutta [7].

In contrast, Tha'mma, belongs to a generation that uprooted itself in 1947. Ghosh's juxtaposition of history and realism with the concepts of freedom, nationhood, and nationality is brilliantly manifested through the character of Tha'mma. Going back to partition of Bengal Ghosh shows cases of Tha'mma's character that was to run between her place of birth and her place of living dating back to the partition of Bengal. Overall, we come across a focus on the personal identity, the struggle with national and political challenges, and the creation of nation, nationality, and nationalism, as well as personal identity constructs.

A person's identity or sense of belonging to at least one state or nation is referred to as nationhood. Nationhood refers to the specific feeling one has about a country that one shares with a group of people, regardless of one's legal citizenship status. Nationhood is defined as "a sense of difference," a "feeling 
and recognition of 'we' and 'they.'" Nationhood can emerge as a united experience as a direct result of the features that emerge from "common opinions" in people's daily lives: nation's history, language, national symbols, national consciousness, and social artefacts. The novel's central theme is India's partition and, as a result, the trauma of East Bengal's partition. The narrator of Ghosh's novel, a young boy who was brought up in post-partition India in Calcutta and Delhi. Partition causes disturbance for three generations. The novel's themes include the agonies of dislocation, the sensation of solitude in the accepted land, and the insatiable longing to return to one's homeland [8] [9].

Ghosh's confrontation with nationalism and national identity is unmistakable in The Shadow Lines. A man's entire reality, present, past, and future, is linked to his own country, native land, or motherland. The Shadow Lines is a story about events that are connected to one another. The majority of the narrative takes place in Calcutta, Delhi, and London, and at times uses them as backdrops for various historical events that defined the Indian Subcontinent, such as the Swadeshi Movement, India's partition, and the communal uprisings of 1963-64 in Calcutta and Dhaka, as well as, to a lesser extent, World War II [10].

The plot revolves around the narrator's grandmother, Tridib, Ila, and May Price, with memories shifting from the past to the present and back again. After Bangladesh was partitioned in 1947, Dhaka was declared the capital. (From East Pakistan) Tha'mma's (Narrator's Grandmother) perception of Dhaka as a home had been dramatically altered by the partition. She was going back to Dhaka as a stranger, not as a native. She, who was born and raised in Dhaka, must confront the harsh reality that Dhaka is no longer her home following 1947. The question that haunted her was, who does she represent? Is she an Indian solely because she is a Hindu and lives in Calcutta? [11].

Dhaka would remain a 'home' only in her memory, a 'home' she couldn't visit, in Calcutta, where she settles after her husband's unexpected death, in the less prosperous area of Bhowanipure. Ila yearned to be free of the suffocating tradition that defined individual events. Ila lives a pre-existing life aboard a pre-existing life of mere survival abroad, free of Indian customs and culture. Ila, in contrast to the narrator's character sketch, remains unimaginative and stagnant, unable to comprehend the narrator's emotion and passion. Ila disregards her roots and seeks refuge in insignificant political events in London, wishing to be a part of European history rather than her own. Ila, a colonial product, rejects her past and community, further defining her as a 'greedy person in the Tha'mma's eyes [12].

She believes she went there for money. Ila's 'Lack of Rootedness' and 'Culture Contradiction' force her to pay the price for being duped by Nick Price. She dismisses her past in favour of her fantasy of freedom, which she believes is only possible in her own 'imaginary' world. What attracted her towards London, was not that there was something extraordinary. She wanted to go there not for happiness but she was desperate to be free. She wanted freedom from the bloodthirsty culture, and free of everyone [13]. Ila rejects everything Indian in The Shadow Lines and attempts to forge her own identity in an alien land. Ila was born outside of India and now travels the world with her diplomat father. She, however, lacks roots. She can't seem to find a place where she belongs. She's lonely and depressed. She marries Nick in an attempt to reject her roots and identify with the West, only to discover that he is cheating her for variety's sake. She is rootless and lost by the end of the novel, clinging to Robi's and members of her family's arms. Her attempt to accept an alien culture fails, and she eventually realises the value of returning home to one's family [14].

Ghosh emphasises the division caused by borders, elaborating on the saying "divide to unite". Partition occurred in 1947, and Dhaka became the capital of East Pakistan, the narrator adds, as if the reference to India wasn't clear enough. After that, there was no way they could think of returning.

Indeed, the Indian partition marks the end of the family's history, as reunification is no longer possible. The documentary The Shadow Lines investigates how the partitions of 1947 and 1971, as well as the subsequent creation of borders, shaped Indian identity [15].

Tha'mma is extremely proud of her heritage, which includes her long-lost family in Dhaka, her sister in another country, and her husband sahib. Tha'mma bears the agonising burden of memory. She carries 
childhood memories, numerous contacts, private, material, and immaterial possessions, but she does not share her sorrows with anyone. She looks at the lake, blankly. Her hometown, Dhaka, has changed so much over the years that she can't reconcile her memories of it with the reality that it now provides [16]. Despite their age, position, beliefs, and shifting perspectives on reality, the narrator, Tridib, and grandmother share a distinct Indian feeling, indeed an expression of nationalism, that Ila, an Indian in the West, cannot imagine or be a part of. For example, the narrator's grandmother is a character who adapts to this way of thinking and for whom the nation serves as a clear indicator of identity. She represents a genuine view of the country against which other characters' perspectives, such as Tridib's, Ila's, and the narrator's, can be judged [17].

Tha'mma clearly values blood and nationhood bonds and is willing to let go of bitter family feuds. To some extent, her freedom is won through bloodshed and violence. It's fascinating to realise that she was captivated by the terrorists and desired to act like them in order to gain her freedom. During her youth, she wished to be a part of the Swadeshi movement and to be able to do anything for the country. When asked if she would have killed the English judge if given the chance, she responds, that she would have been scared, but would have pleaded for strength, and God willing, she would have killed him [18].

Tha'mma's imagination is constrained by the concept of nationalism. Tha'mma had no idea her nationalism and sense of freedom had destroyed her home and spilled her kin's blood. She was of the opinion that there is a need to destroy them before they could cause the worst damage. She refuses to acknowledge that, in the absence of war, national liberty guarantees individual liberty until the very end. Her militant nationalism is on display when she explains the Englishmen's creed and applies it to the Indian context, as follows: War is their religion. That is what it takes to build a nation. When this happens, people forget whether they were born this way or that, Muslim or Hindu, Bengali or Punjabi: they are revealed to be a family descended from the same pool of blood. She felt it is ones bound duty to contribute their best to India [19].

She has an unexplainable attachment to the family jewellery, despite her willingness to sell it to raise funds during riots. In 1965, she donates her prized chain, which was the first gift she received from her husband after their marriage, to the war fund. She justifies her actions to her grandson, by saying, that she had donated it to the war fund, as she had no other choice and the utmost necessity was freedom of the nation. Continuing to be united and assassinating them before they assassinate or destroy should be the priority [20]. She feels often they may not be opportunities and the right time has come to strike the enemies with finally, with tanks, guns, and bombs, we're fighting them properly. Her desire for liberty is undeniably a desire for nationhood, for which she is willing to pay any price.

Tha'mma, on the other hand, believes that Ila does not understand the true spirit of England and therefore does not have the right to stay in the country. Everyone who lives there has earned the right to be there through blood: through the blood of their brothers, fathers, and sons. Because they've drawn their borders in blood, they know they're a nation. Despite the fact that she lives in a frozen past, the reality of nationhood in her case is fairly consistent. She is worried about her elderly uncle dying in a foreign country, nearly abandoned and alone in his old age, as a devout militant nationalist. She tells her son whether they recognise each other doesn't matter, but still they are the same flesh, blood, and bone, and maybe after many years, they would be able to make amends for their bitterness and hatred [21].

When Tha'mma goes on a rescue mission to Dhaka to return her Jethamoshai to India, her sense of belonging to the country is shattered. When Tha'mma returns to her motherland of Dhaka (Bangladesh) after several years and for the first time since partition, her beliefs about nation, religion, and belonging begin to be shaken. She wonders if she can see the India-East Pakistan border from the plane window before she leaves. She is surprised to learn that she will not be able to see any dividing line between India and East Pakistan from the plane because in the modern world, borders are crossed within airports when disembarkation forms with information about nationality, date of birth, place of birth, and so on are filled out. When Tha'mma discovers that the border isn't actually on the border, she is completely perplexed [22] [23]. The narrator expresses his feelings by saying: that his grandmother's eyes widened, 
with an expression of surprise while it was not until many years later that she realized that she had to fill in the form "Dhaka" as her birthplace, and the prospects have been troubled. For her, because she prefers neatness and order, she can't understand how her birthplace and her identity have become so confused.

Tha'mma's disillusionment grows when she is asked to fill out a passport form with her place of birth during her visit to Dhaka. Tha'mma's decision to flee Dhaka during the partition meant leaving behind old roots in search of new stability and identity. As a result, when she visits Dhaka years later, she is upset to write 'Dhaka' as her birthplace [24].

Jethamoshai, on the other hand, sees Calcutta as a 'foreign' land, much like Tha'mma sees Dhaka. It's no surprise that he stubbornly refuses to leave, despite being informed that the communal violence in Dhaka has made his stay with non-natives dangerous. Jethamoshai is senile and bedridden, but he has a better grasp of reality, he believes that geographical boundaries are pointless and unnecessary because of India's political unrest. When they tried to persuade Jethamoshai to join them in Dhaka, a riot broke out, and a mob attacked them. All three assassins were killed: the old man, Tridib, and Khalil [25].

When Tridib is murdered in post-colonial Dhaka by a violent Muslim mob that has organised itself across borders, similar to other Hindu and Muslim mobs, Tha'mma loses her grip on reality. The HinduMuslim riots are an example of violence that has eluded the government's authority and control because it is not organised and contained. This uprising was sparked by the Hazratbal incident in faraway Kashmir. When the holy Relic is displayed, the Hazratbal monument, which houses it, has become a major pilgrimage site, with crowds of Kashmiris of all religious faiths flocking to the sanctum. On December 27, 1963, the Mu-i-Mubarak was relocated to Kashmir, after 263 years in the Hazratbal mosque. The national outpouring of grief was quickly destabilised by destabilising political and religious forces. The communal unrest in Khulna spread to Dhaka and then to Calcutta, where it was mirrored. It was unimportant news for the people of other states. The author appears to be uniting those who are one while projecting hazy and unreal boundaries [26] [27].

The outbreak of violence occurs outside of the rhetoric of organised warfare with adversaries across borders, destabilising the established national conversation and description of events that have occurred and subsided, followed by the story of Tridib's death several years later. Ghosh first introduces Robi, Tridib's younger brother. Tridib's death cements his place as an advocate for a postcolonial Indian identity. Robi, who was born in the post-colonial period, has grown up with the identity of an independent Indian citizen and has never faced decolonization or partition. His participation in the Bangladesh uprising, which resulted in the death of his brother, qualifies him as an Indian awareness ambassador [28] [29].

The real tragedy of partition was the abrupt end of a long and communally shared history and national heritage. Relationships between Hindus and Muslims were not without disbelief, suspicion, or angry rejection of the other group's habits and practises by one group, but such instances of active wickedness and communal confusion were a rare exception to the common bonds of mutual goodwill and warm approaches of close brotherhood [30].

Not only Tha'mma, but also the narrator, May Price, and Nick Price, feel at home in a variety of settings. The narrator, who grew up in a particular social and cultural environment, is uprooted from his safe environment and forced to travel indefinitely in pursuit of academic and professional excellence. $\mathrm{He}$ travels to Delhi, London, and other cities and discovers that the mission is ultimately futile. As a result, individual relationships are in a state of confusion, chaos, and disorder.

\section{CONCLUSION :}

Historiographic Metafictional works are never finished, and the last page of a novel is left open for the reader to interpret. Readers have the freedom to draw their own conclusions. Because Amitav Ghosh uses historiographic metafiction, a postmodernist literary technique, he does not provide a conclusion at the end of The Shadow Lines, leaving readers sceptical. 
Ghosh looks into the strangeness and irrationality of traditional identities like nation, nationality, and nationalism. He has emphasised this in three ways: (1) political borders are questioned and shown to be arbitrary as they are drawn arbitrarily by politicians, (2) the idea of nation as a homogeneous entity is compared with inhumane activities poisoning the brotherly relationship among different races of the country, and (3) the created border is discovered - showing identical scenes of violence across the border on the one hand and a sense of oneness with people from other countries on the other. Ghosh attempts to create an image of global protection in "The Shadow Lines" by incorporating various cultures and creating a unified universal picture with a single entity and reality.

The shadow line that divides the two countries is similar to an imaginary border line. This imagery shadow line found on atlases has caused personal problems for a number of people. A traumatic situation is created in the minds of the locals when a similar line is formed or fixed. As a result of the new line, they find themselves in an unneeded bind. I simply attempted to identify the situations and scenes depicted in the novel The Shadow Lines in this research paper.

This isn't a story about the grandmother or Jethamoshai in particular; rather, it's a description of a specific type of historic and ethnographic notion of past realities and events. It's the story of every man who bounces back and forth between the past and the present, the nation and the state, historical motifs and descriptive anthropology, and so on. The narration of the novel comes to an end, but it is not completed. It raises serious concerns about our ancestors, identities, and issues such as "What is the point of going to war? What is causing the rioting? Why do we split up? What is the purpose of borders? What is the purpose of shadow lines?"

Ghosh's novel The Shadow Lines ends abruptly because he does not tell his readers what happens to the characters. How is Ila's marriage to Nick Price going, and is she happy with him? The novel of Amitav Ghosh does not have a conclusion because he has left it up to the readers to draw their own conclusions by expressing their own points of view.

Two generations of migrant women, the grandmother and Ila, serve as figures in this novel, representing various types of nationality and migration viewpoints made common by globalisation. To summarise, the world is not as simple as the atlas depicts it, but there are numerous unavoidable facts hidden within those solid lines that have resulted in political aggression and violent bloodshed.

\section{REFERENCES :}

[1] William H Gass (1978). Fiction and the Figures of Life. David R. Godine, Publisher, ISBN : 9780879232542.

[2] Almond, I. (2004). Post-colonial melancholy: An examination of sadness in Amitav Ghosh's The Shadow Lines. Orbis Litterarum, 59(2), 90-99.

Google Scholar $x^{7} \quad \underline{\text { CrossRef/DOIX }}$

[3] Bose, B., \& Gandhi, L. (2000). Postcolonial theory: A critical introduction. World Literature Today, 74(1), 254-270.

Google Scholar $x^{\nearrow}$

[4] Kasikhan, H. R., \& Kasikhan, N. (2015). Postcolonial approach to Amitav Ghosh's The Shadow Lines. Mediterranean Journal of Social Sciences, 6(4), 247-255

Google Scholar $7 \quad$ CrossRef/DOIX

[5] Mondal, A. A. (2003). Allegories of identity: "Postmodern" Anxiety and "Postcolonial" Ambivalence in Amitav Ghosh's in an antique land and The Shadow Lines. The Journal of Commonwealth Literature, 38(3), 19-36.

Google Scholar $\chi^{7} \quad$ CrossRef/DOIX

[6] Bera, R. (2017). Decolonization of mind in Amitav Ghosh's writing: A postcolonial study of The Shadow Lines. IJOHMN (International Journal online of Humanities), 3(2) 1-8.

Google Scholar 7 
[7] Bhavani, P., \& Kannadhasan, D. (2019). The conflict of nation and partition in Amitav Ghosh's The Shadow Lines. History Research Journal, 5(4), 59-66.

Google Scholar $X^{\nearrow} \quad \underline{\text { CrossRef/DOI }{ }^{\nearrow}}$

[8] Ghosh, A., \& Amitav. (2010). The Shadow Lines. Penguin Books India, 1(1), 128-159.

CrossRef $x^{\top}$

[9] Bharali, P. (2012). Amitav Ghosh's "The Shadow Lines": Problematics of National Identity. IOSR Journal of Humanities and Social Science, 2(2), 44-46.

Google Scholar X

[10] Black, S. (2006). Cosmopolitanism at home: Amitav Ghosh's The Shadow Lines. The Journal of Commonwealth Literature, 41(3), 45-65.

Google Scholar 7 CrossRef/DOI 7

[11] Chowdhary, A. (2002). Amitav Ghosh's The Shadow Lines: Critical essays. Atlantic Publisher \& Dist, 1 (1), 43-46.

Google Scholar $x^{7}$

[12] Prasad, Murari. "Amitav Ghosh's The Shadow Lines: Re-Reading its Craft and Concerns". Asiatic, 2(1), 69-82.

Google Scholar $\not^{7}$

[13] Mondal, S., \& Gaur, R. (2017). Reading nationality and other layers of identity in Amitav Ghosh's, The Shadow Lines. South Asian Review, 38(2), 29-47.

Google Scholar X $\quad \underline{\text { CrossRef/DOIX }}$

[14] Roy, B. (2014). Mapping the Transnation: Amitav Ghosh's The Shadow Lines. Crossroads. A Journal of English Studies, 5(2), 16-31.

Google Scholar X'

[15] Amitav Ghosh (2017). An ethics of mourning: Loss and transnational dynamics in The Shadow Lines. Postcolonial Gateways and Walls, 195(2), 241-251.

Google Scholar ${ }^{\top}$

[16] Kaul, S. (1994). Separation anxiety: Growing up inter/National in Amitav Ghosh's The Shadow Lines. Oxford Literary Review, 16(1), 125-145.

Google Scholar $\chi^{7}$

[17] Dhiman, P. (2021). Discovering shadow lines and their effects on nationalist identity in Amitav Ghosh's The Shadow Lines. International Journal of English Literature and Social Sciences, 6(3), 314316.

Google Scholar $\chi^{7}$

CrossRef/DOIX

[18] Kokila, S. (2011). Amitav Ghosh: Transfiguration of memory and imagination in The Shadow Lines. Indian Journal of Applied Research, 1(6), 89-90.

Google Scholar $X^{\nearrow} \quad \underline{\text { CrossRef/DOI }}$

[19] Kalyan Pattanayak. (2021). Amitav Ghosh' The Shadow Lines: Mapping cross border identity. The Creative Launcher, 6(3), 118-122.

Google Scholar 7 CrossRef/DOI 7

[20] Bagchi, N. (1993). The process of validation in relation to materiality and historical reconstruction in Amitav Ghosh's The Shadow Lines. MFS Modern Fiction Studies, 39(1), 187-202.

Google Scholar $X^{\nearrow} \quad \underline{\text { CrossRef/DOIX }}$

[22] Chakrabarty, D. (1995). Remembered villages: Representations of Hindu-Bengali memories in the aftermath of the partition. South Asia: Journal of South Asian Studies, 18(1), 109-129.

Google Scholar $x^{\prime}$

CrossRef/DOIX

[23] Desai, G. (2004). Old World orders: Amitav Ghosh and the writing of nostalgia. Representations, 85(1), 125-148. 
Google Scholar $X^{7}$

CrossRef/DOIX

[24] Amitav Ghosh (2021). Imagining identities amidst shifting Spatialities in Amitav Ghosh's the shadow lines. Amitav Ghosh's Culture Chromosome, 216 (2), 273-285.

Google Scholar

[25] Jackson, E. (2021). Cosmopolitan attitudes and cosmopolitan identities in Amitav Ghosh's The Shadow Lines. South Asian Review, 24(1),1-13.

Google Scholar $x^{7}$

CrossRef/DOIX

[26] Kulsum, U., \& Kaiser, N. (2013). Lost in contrasted strands of dislocated identity: A study of two Diasporic characters, Tha'mma and Ila in Amitav Ghosh's The Shadow Lines. Stamford Journal of English, 4(1), 62-76.

Google Scholar 7

\section{CrossRef/DOIX}

[27] Rao, N. (2003). Cosmopolitanism, class and gender in The Shadow Lines. South Asian Review, 24(1), 95-115.

Google Scholar $\square$

CrossRef/DOI $\square$

[28] Roy, A. (2000). Microstoria: Indian nationalism's 'Little stories' in Amitav Ghosh's the shadow lines. Journal of Commonwealth Literature, 35(2), 35-49.

Google Scholar $\square \quad$ CrossRef/DOIf

[29] Saiel, M. F. (2021). Alienated suffering of divide and cross: A study of Amitav Ghosh's the shadow lines. International Journal of English Literature and Social Sciences, 6(6), 39-45.

Google Scholar $X^{\top}$

[30] Zobaer, S. (2020). Pre-partition India and the rise of Indian nationalism in Amitav Ghosh's 'The shadow lines'. Rainbow: Journal of Literature, Linguistics and Cultural Studies, 9(2), 156-165.

$\underline{\text { Google Scholar } \square}$

[31] Hutcheon, L. (2003). A poetics of Postmodernism: History, theory, fiction. Routledge. 1(1), 1-178. Google Scholar $X^{\top}$

$* * * * * * * * * *$ 